International Journal of Biology, Pharmacy and Allied Sciences (IJBPAS) 'A Bridge Betuen Caboratory and QRendor'

WwW.jibpas.com

\title{
APPLICATION OF GEOGRAPHIC INFORMATION SYSTEM AND TOURISM POTENTIAL OF FORTS IN RAIGAD DISTRICT
}

\section{HARPALE DATTATRAYA $\mathbf{V}^{1^{*}}$ AND HARANE SMITA $\mathbf{S}^{2}$}

1: HPT Arts \& RYK Science College, Nashik- 05

2: Art, Science \& Commerce College, Surgana, Nashik

"Corresponding Author: Harpale Dattatraya V: E Mail: harpalesir@gmail.com

Received $10^{\text {th }}$ June 2021; Revised $11^{\text {th }}$ July 2021; Accepted 20 ${ }^{\text {th }}$ Aug. 2021; Available online $15^{\text {th }}$ Jan. $_{2022}$

\section{https://doi.org/10.31032/IJBPAS/2022/11.1.1046}

ABSTRACT

India is a developing nation. Tourism is one of the sectors supporting to national economy e.g. Southeast Asian Countries like Singapore, Switzerland, Hong-Kong, Maldives have tourism-based economy. Tourism industry is rapidly growing tertiary activities in India. Geographical variation provides greater scope for the tourism development in Maharashtra. Maharashtra has four physiographic divisions namely Plateau region, Wester Ghat and Kokan region. Theses physiographic variation provides lots of places of interest in the states. In this present research work geographic information system and tourist information system is used for the development of potential tourism site in Raigad districts of Maharashtra states. Present study is useful for the researcher, planners, government officer, administrator, geographer, economist etc. Such study will be helpful to provide employment opportunities, regional development, infrastructure facilities, health facilities, sustainable tourism, and ecotourism in the study region.

\section{Keywords: Tourist Information System (TIS), GIS, planner}

\section{INTRODUCTION}

The geographical factors physical and cultural provide better opportunities to develop tourist places like hill station, medical tourism, health tourism, sport tourism, national park, sanctuaries, adventure tourism, pilgrim tourism, historical monument, archeological sites, water sport activities, lakes, waterfall, hot water spring, tribal culture, festival, food style, music etc. From last three decades of $20^{\text {th }}$ century, computer revolution has boosted the tourism development through media 
advertising publicity. In the $21^{\text {st }}$ century GIS has added in this list. In the present study geographic information system used for the tourism development for the developed and under developed tourist places. Now a days governments give priority to for the development of the tourism sector for the creation of the employment opportunities.

\section{STUDY AREA}

The total population of the Raigad district is 2634200 as per the census 2011. Raigad district consist of 15 tehsils namely Mangaon, Shrivardhan, Mhasla, Panvel, Karjat, Khalapur, Alibag, Murud, Roha, Tala, Sudhagad, Poladpur, Uran, Mahad, Pen etc. The location of the study area is $17^{\circ} 51^{\prime}$ to $19^{\circ}$ $80^{\prime} \mathrm{N}$ Latitude and $72^{\circ} 51^{\prime}$ to $73^{\circ} 40^{\prime}$ E Longitude. The total geographical area of the district is 7152 sq. $\mathrm{km}$. The district headquarter is located at Alibag city. The total length of the coastline of the district is $240 \mathrm{~km}$ available for the navigation. The district is bounded by Satara, Ratnagiri and Arabian Sea (Fig. 1).

\section{OBJECTIVES}

1) To study the available tourism facilities in the study region.

2) To prepaid attribute data of the tourist places in the study area with geographic information system and tourist information system.

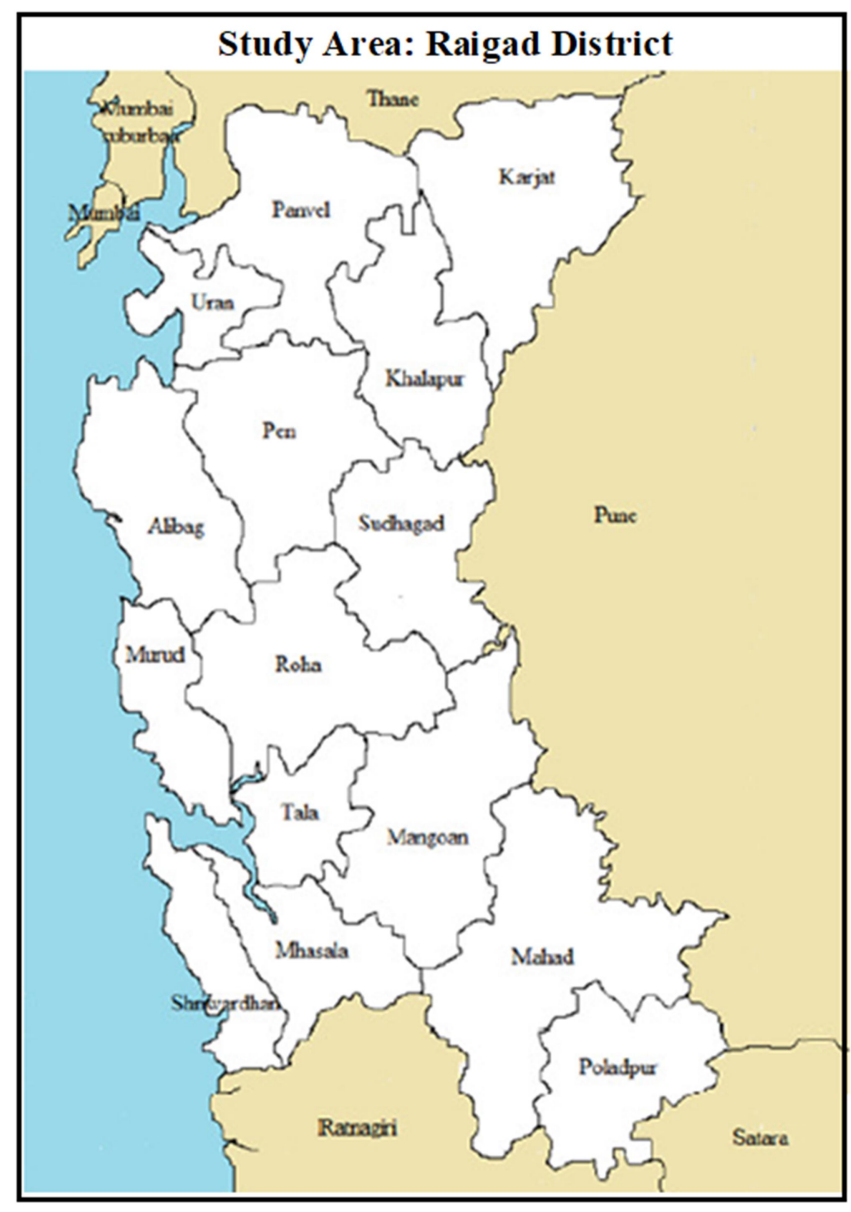

Fig. 1 
Table 1: Administrative division of Raigad district

\begin{tabular}{|c|c|c|c|c|c|}
\hline SN & $\begin{array}{c}\text { Name of } \\
\text { Sub-division }\end{array}$ & Name of Tehsil & $\begin{array}{l}\text { Area } \\
\mathbf{K m}^{2}\end{array}$ & $\begin{array}{c}\text { No. of } \\
\text { Villages }\end{array}$ & Population 2011 \\
\hline \multirow{3}{*}{1} & \multirow{3}{*}{ Alibag } & 1. Alibag & 500 & 218 & 236167 \\
\hline & & 2.Pen & 499 & 171 & 195454 \\
\hline & & 3. Murud & 231 & 74 & 74207 \\
\hline \multirow{4}{*}{2} & \multirow{4}{*}{ Panvel } & 1. Panvel & 631 & 177 & 750236 \\
\hline & & 2. Uran & 184 & 62 & 160303 \\
\hline & & 3. Karjat & 665 & 184 & 212051 \\
\hline & & 4. Khalapur & 183 & 141 & 207464 \\
\hline \multirow{4}{*}{3} & \multirow{4}{*}{ Mangaon } & 1.Mangaon & 683 & 187 & 159613 \\
\hline & & 2.Sudhagad & 467 & 98 & 62380 \\
\hline & & 3.Roha & 643 & 162 & 167110 \\
\hline & & 4.Tala & 250 & 61 & 40619 \\
\hline \multirow{4}{*}{4} & \multirow{4}{*}{ Mahad } & 1.Mahad & 1,257 & 183 & 180191 \\
\hline & & 2.Poladpur & 373 & 87 & 45464 \\
\hline & & 3.Mhasla & 236 & 84 & 59914 \\
\hline & & 4.Shrivardhan & 120 & 78 & 83027 \\
\hline & Total & 15 & 7152 & 1967 & 2634200 \\
\hline
\end{tabular}

(Source: Census, 2011)

\section{DATABASE \& METHODOLOGY}

The Geographic Information System and potential of fort in Raigad district, for that primary and secondary data is used for study. The present research work is done on this topic are referred from previous study the internet, magazine, journal publication, MTDC, ITDC visit, SOI toposheet, census data 2011, socio-economic abstract, tourist map, atlas, gazetteers, district resource map. The questionnaire was prepared for the present study. The field visit was conducted to collect the primary data, secondary data, photograph, GPS location; digital elevation model is prepared with help of
GIS software and non-spatial data attribute is prepared with the help of primary and secondary data. The various statistical techniques are used to analysis the data. The above information and maps with help of GIS software, Arc GIS and Geomatica various thematic layers are generated. The thematic layers are analyzed to demarcate tourism potential sites and site suitability. The various maps are prepared with the help of GIS software. On the basis of study results and conclusions were made. In this map we using Open Street map Layers for Raigad district. In this data Point Locations, Roads, Railway network, Drainage Network is used. 


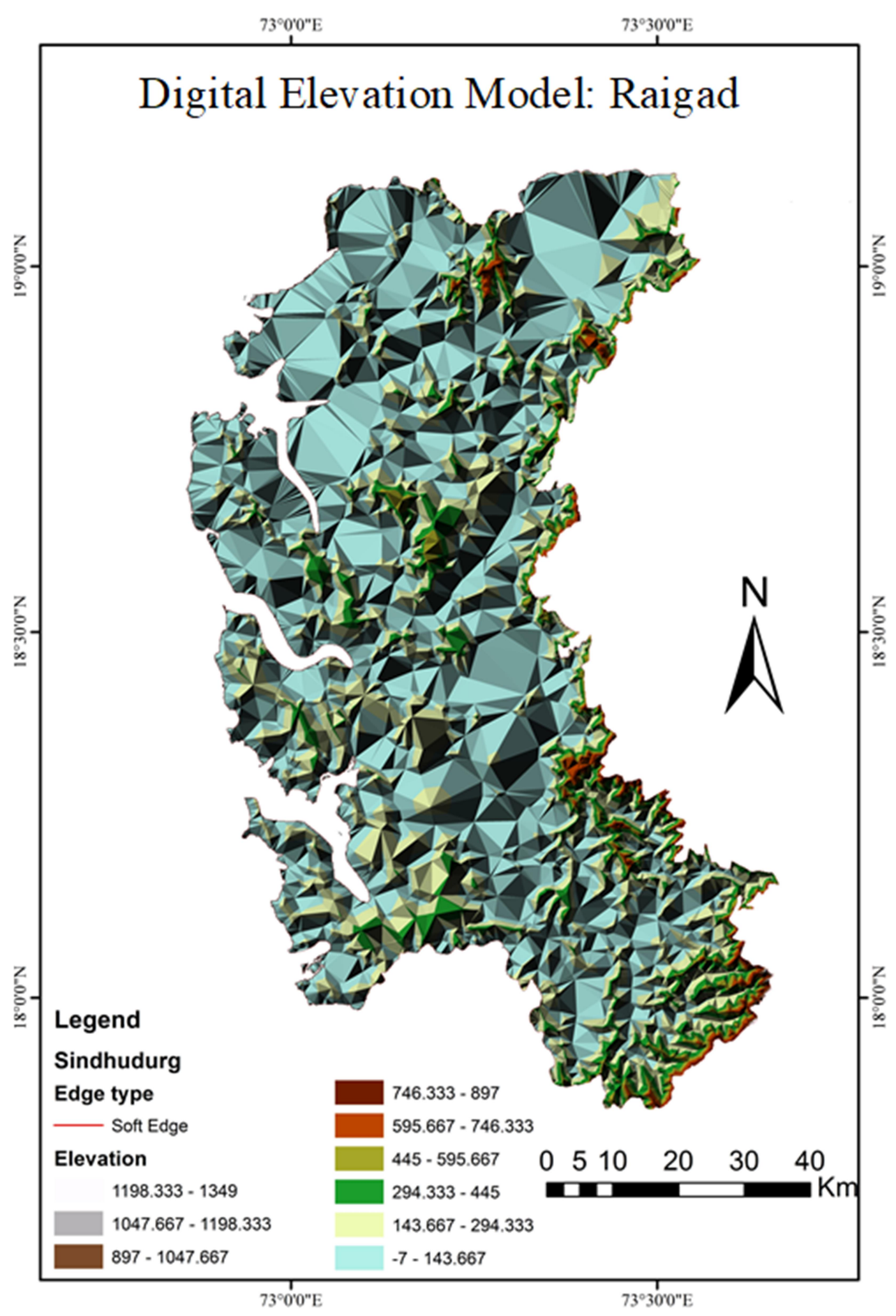

Fig. 2

RESULT AND ANALYSIS

The tourism potential forts are analysis with 
the help of sites suitability parameters namely natural attraction, transportation, security, tourist guide, vegetation, recreation, entertainment, vegetation, communication accommodation, other infrastructure facilities. There are total 11 parameters are used for to find out the potential forts in the Raigard district. The primary data were collected during the field work conducted in the various time of the year ie. Diwali, Christmas, Chhatrapati Shivaji Maharaj Jayanti, Republic day, Independence day etc. The matrix is prepared for the collated data and weighted index method is used for the analysis of the data and result is prepared (Fig. 3).

\section{CLASSIFICATION OF NEW POTENTIAL}

\section{SUITABLE SITES}

The forts in the Raigad district are analysis with the help of weighted index method and they are classified namely least, moderate and highly suitable forts. As per the result Raigad, Kolaba, Murud forts score 56, 41 and 43 respectively are the highly suitabale forts. Revdanda, Sudhagad and Karnala forts score respectively 37,36 and 35 are the moderate suitable sites. The Kothaligad forts score 27 is least suitable fort in the Raigad district.

\section{REMEDIES TO OVERCOME THE PROBLEM -}

To developed tourism in potential sites in the Raigad district following facilities should be developed in the study area. In the study area tourist, guide, accommodation, entertainment, drinking water, security, parking facilities, public transport, market should provided to tourists at Raigad, Karnala and Revdanda.

\section{CASE STUDIES}

Using this tourist information system one can may be layman or tourist get correct information about particular location.

\section{Murud - Janjira}

Janjira fort is located in Murud tehsil of Raigad district (Fig. 4). The Murud fort is sea fort in the Raigad district.

Table 2: Weighted index analysis of forts in Raigad district

\begin{tabular}{|c|c|c|c|c|c|c|c|}
\hline $\begin{array}{l}\text { Potential fort } \\
\text { Parameter }\end{array}$ & $\begin{array}{c}\text { Murud- } \\
\text { Janjira }\end{array}$ & Karnala & Kolaba & Revdanda & Sudhagad & Raigad & Kothaligad \\
\hline Natural attraction & 5 & 5 & 5 & 5 & 5 & 5 & 4 \\
\hline pleasant weather & 5 & 4 & 4 & 5 & 5 & 5 & 3 \\
\hline Vegetation & 5 & 4 & 4 & 5 & 4 & 4 & 4 \\
\hline Road & 5 & 3 & 3 & 3 & 4 & 5 & 3 \\
\hline Public Transport & 5 & 3 & 3 & 2 & 3 & 5 & 2 \\
\hline Accommodation & 3 & 1 & 2 & 1 & 1 & 4 & 1 \\
\hline Adventure tourism & 2 & 3 & 4 & 4 & 3 & 5 & 5 \\
\hline Recreation & 4 & 4 & 4 & 3 & 3 & 5 & 1 \\
\hline Pay and Parking & 3 & 3 & 2 & 3 & 1 & 5 & 1 \\
\hline Fresh Water & 1 & 2 & 3 & 2 & 2 & 5 & 1 \\
\hline Medical facility & 2 & 2 & 4 & 1 & 2 & 4 & 1 \\
\hline Communication & 3 & 3 & 3 & 2 & 2 & 4 & 1 \\
\hline Total weight & 43 & 37 & 41 & 36 & 35 & 56 & 27 \\
\hline
\end{tabular}

Source: data complied by author on the basis of field visit 2020 . $(* 1,2,3,4,5$, weighted values) 
Table 3: Result analysis

\begin{tabular}{|c|c|c|}
\hline Potential site & Score & Result \\
\hline Murud- Janjira & 43 & Highly suitable \\
\hline Karnala & 37 & Moderately suitable \\
\hline Kolaba & 41 & Highly suitable \\
\hline Revdanda & 36 & Moderately suitable \\
\hline Sudhagad & 35 & Moderately suitable \\
\hline Raigad & 56 & Highly suitable \\
\hline Kothaligad & 27 & Least suitable \\
\hline
\end{tabular}

Source: Field Survey, 2021

\section{Classification of potential forts in Raigad district}

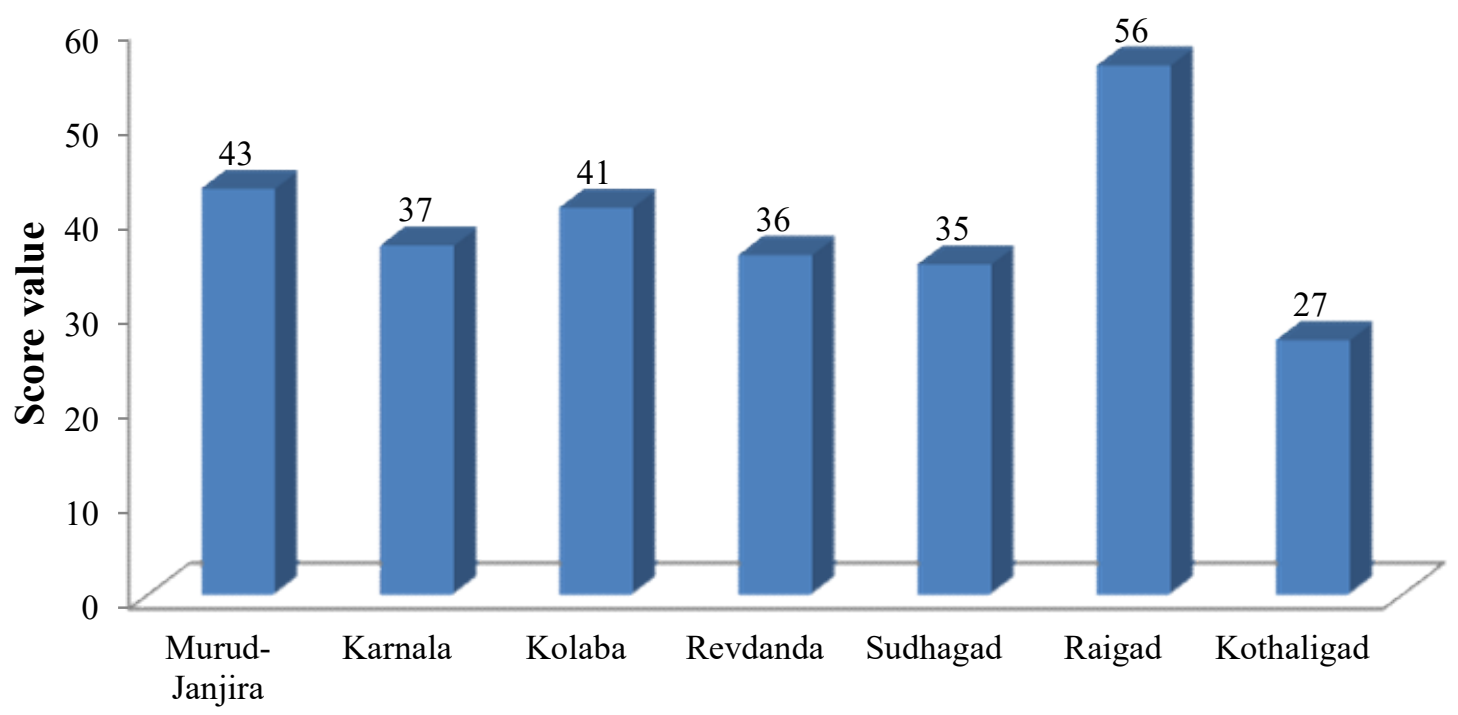

Forts

Fig. 3 


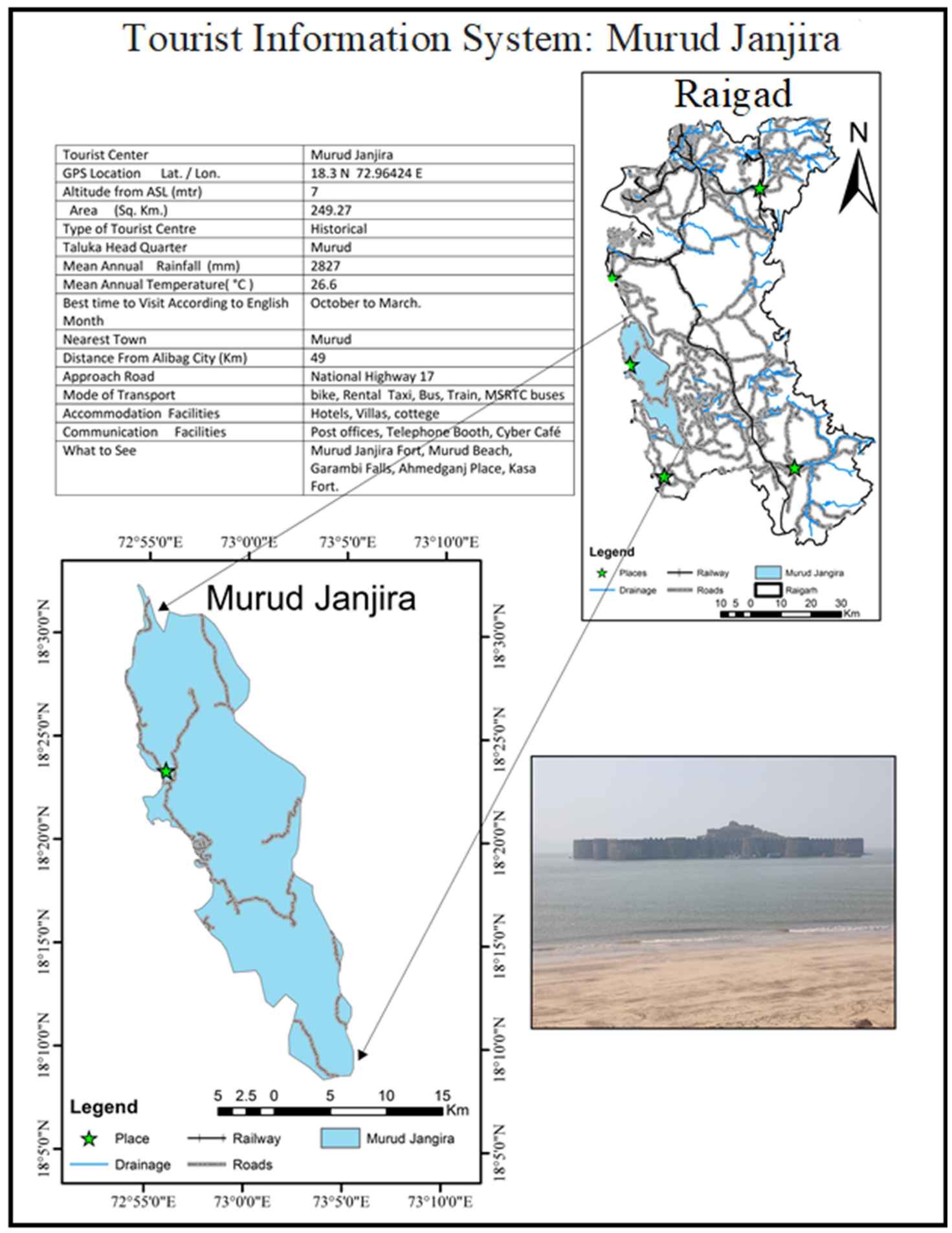

Fig. 4 


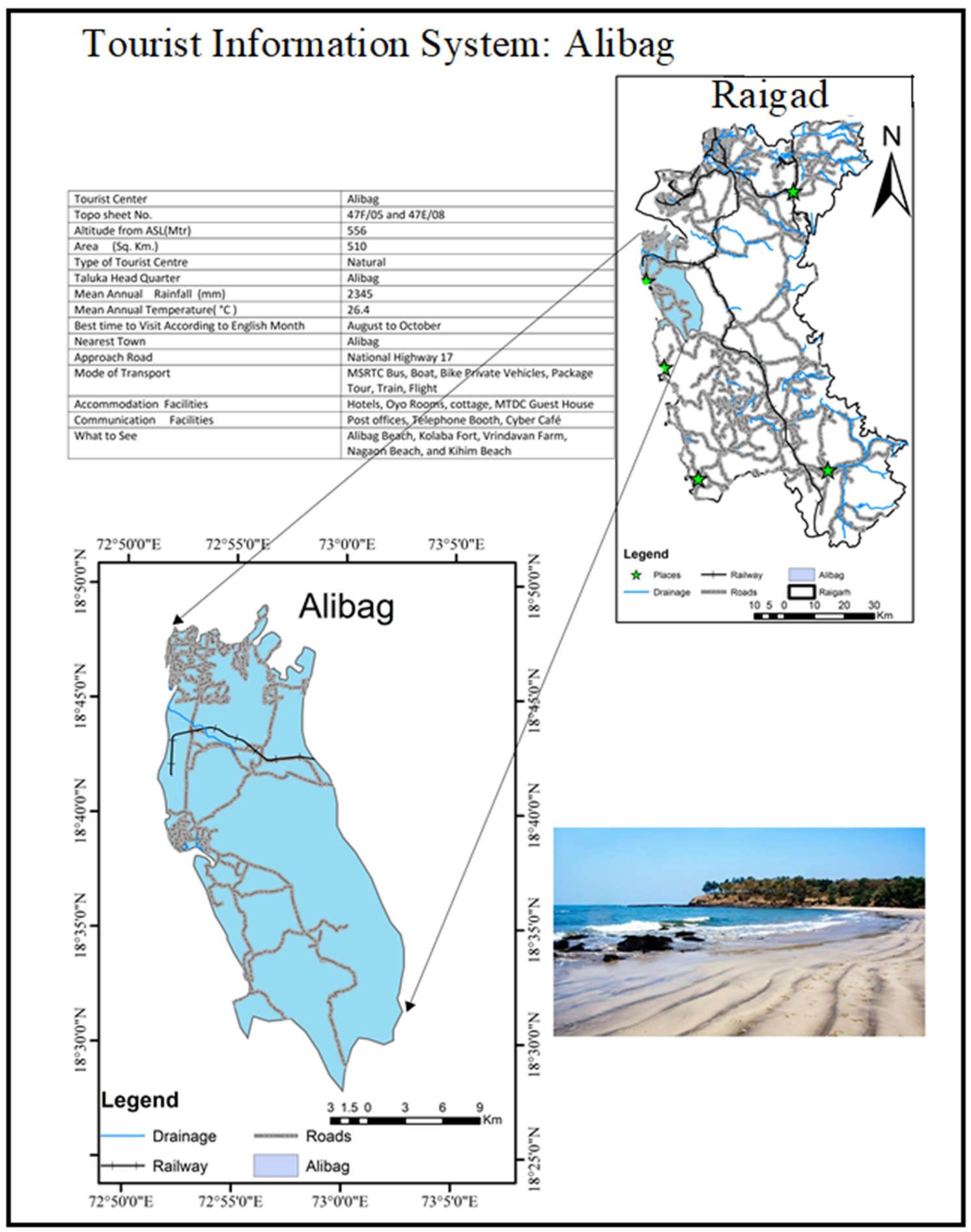

\section{CONCLUSION}

Various tourist zones according to tourist category can be demarcate or generated with the help of GIS. The historical places along the Kokan
Fig. 5

railway or Raigad-Goa National highway map will be prepared. With the help of such type of T.I.S. (Tourist Information System) one can conclude or identify accounts of the needs and potentials of 
rural areas and economically weak or poor. Present study is useful for the researcher, planners, government officer, administrator, geographer, economist etc. Such study will be helpful to provide employment opportunities, regional development, infrastructure facilities, health facilities, sustainable tourism, and ecotourism in the study region.

\section{REFERENCES}

[1] Akmanchi Anand, (2002). Pune fire emergency management information system, Project report submitted to IIRS, Dehradum.

[2] Harpale, D.V. (2009). "Identification of New Tourist Centers and Their Site Suitability A Case Study of Pune District Maharastra State unpublished thesis.

[3] Harpale, D.V. (2013-2015). "Potential in GIS and Tourist Information System TIS, A Case Study of Nashik District, UGC Minor Research Project, New Delhi.

[4] Kathe, M. H. (2010). A Geographical Study of Changes in Sugarcane Production Area in Junnar Tahsil, unpublished thesis.

[5] Lo, C.P. and Yeung (2004). Concept and Techniques of Geographic Information System, Prentice -Hall of India Private Limited, New Delhi, 110001.
[6] Nagarale, V.R. (2007). 'Site Suitability for Tourism Development with the help of GIS, A Case Study of Pune District Maharashtra' UGC Minor Research Project.

[7] Navale, A. M. \& Deshmukh, S. B. (1989): A View on Pilgrimage Tourism. - A study in Human Geography, The National Geographical Journal of India, Vol. 33.

[8] Pani Padmini, (2004). Geospatial Modeling for Identifying Aesthetic Spot for Tourism in a hilly Region, Project report submitted to IIRS, Dehradum.

[9] Patil, Rakesh V. (2011). Ecotourism Potential of Salher Fort, Nashik District International Refereed Research Journal, research world.com EISSN2229-4686-ISSN-2231-4172

Vol.- II, Issue -4,Oct. 2011 pp. 135142.

[10] Perce Douglas (1989): Tourist Development, Longman Scientific \& Technical Longman Group, U.K. Limited, London Co - published in the United States with John Wiley and sons, INC, New York.

[11] Reddy, Anji (2001). 'Textbook of Remote Sensing and Geographical 
Information System (Second edition)

B S Publications, Hyderabad.

[12] Shinde, S.B. (2018). Assessment of Tourism Potential of Major Forts in Pune District, Maharashtra, unpublished thesis.

[13] Thorat, S. D. \& Suryawanshi, R.S. (2017). Assessment Of Agro-Tourism Potential In Junnar Tehsil, Maharashtra, India, paper published in Scholarly Research Journal for Interdisciplinary Studies, Vol. - 4/36 2017.

[14] Village and Town Directory of Nashik 2011: Director of Census operation, Maharashtra, Mumbai.

[15] website.www.google.

[16] Sajja, G., Mustafa, M., Phasinam, K., Kaliyaperumal, K., Ventayen, R., \& Kassanuk, T. (2021). Towards Application of Machine Learning in
Classification and Prediction of Heart

Disease. 2021 Second International Conference On Electronics And Sustainable Communication Systems (ICESC).

https://doi.org/10.1109/icesc51422.20

\subsection{0}

[17] Veluri, R., Patra, I., Naved, M., Prasad, V., Arcinas, M., Beram, S., \& Raghuvanshi, A. (2021). Learning analytics using deep learning techniques for efficiently managing educational institutes. Materials Today: Proceedings.

https://doi.org/10.1016/j.matpr.2021.1

\subsection{6}

[18] C.M. Thakar, S.S. Parkhe, A. Jain et al., 3d Printing: Basic principles and applications, Materials Today: Proceedings, https://doi.org/10.1016/j. matpr.2021.06.272 